\title{
地球・月間宇宙航行のための衛星利用航法についで1
}

\section{A Study on Satellite-Based Navigation Applied for Earth-to-Moon Flying Spacecraft}

\author{
山 脇 功 次 ${ }^{* 2}$ \\ Koji YAMAWAKI
}

Key Words: Satellite Navigation, GPS, DOP

\begin{abstract}
This paper discusses the satellite based navigation which is applicable for the guidance of spacecrafts flying near the moon and positioning of vehicles moving about the surface of the moon. Several geosynchronous satellites are supposed to be used as range-finding signal sources because the suitable deployment, precise orbit determination and clock correction of these satellites must be performed for accurate navigation. This paper also studies a method of the user's clock synchronization which is useful for the improvement of navigation accuracy, and suggests that the use of very high stable clocks to user equipments is effective for the reduction of frequencies of bi-directional communications by which user's clock synchronization with the satellite's clock is performed.
\end{abstract}

\section{1. 序}

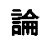

1970 年代前半より今日まで, GPS/NAVSTAR は 全世界に散在するすべての移動体に適用できる航法手 段として開発されてきたが，GPSを人工衛星や宇宙 往還輸送機等の宇宙航行体の航法手段として利用しよ うとする研究1)も当初より並行して進められている.

GPSが地球観測衛星やスペースシャトル等の比較 的低軌道の宇宙航行体の航法に適用される場合は，高 速飛行中での測距電波処理の追従性と慣性飛行中での 軌道ダイナミクスの精密モデリングが新たな課題とな るが。これらの点を除けば，宇宙用 GPS 受信機に対 する機能性能上からの要求課題は航空機や船舶に適用 されるGPS 受信機の場合と大差がない。また，GPS 衛星の配置条件や測距電波の送信条件に関しても，大 きな変更の必要性はない。

しかし，宇宙航行体(以下では宇宙機と呼ら゙)が GPS 衛星の軌道半径を越えて地球よりはるかに離れ

*1 平成 5 年 5 月 14 日原稿受理

*2 宇宙開発事業団筑波宇宙センター
る場合は，GPSより送信される測距電波の受信電力 が距離の 2 乗に反比例して弱くなるため，擬似レンジ の測定が困難となる。そればかりか．すべての GPS 衛星が局所(地球の周辺)に集中して見えることにな り、 4 基以上の衛星からの測距電波が受信できる場合 でも良好な測位精度は得られないという衛星配置上の 幾何学的問題が生じる.

この論文では，GPSのように地球の周辺に配備さ れた衛星群を測距基準点として，地球より遠く隔てた 位置での衛星航法の精度について考察する。特に，地 球・月間宇宙航行のための衛星航法においては，測位 精度は測距衛星の受信可能(可視ともいう)基数や配置 関係だけでなく，地球・宇宙機間レンジの衛星軌道半 径に対する比率 $\gamma$ (以下ではこれを離隔率と呼ぶ)に 左右されることに注目して，測位精度の尺度となる測 位劣化指数(測位誤差をレンジ測定誤差で割った值で DOP と呼ぶ）と上記の離隔率 $\gamma$ との関係を導く

次に，測距電波源として地球同期衛星のような高高 度衛星を適用しても，宇宙機が月に近接した軌道や月 面近傍にあるために，離隔率 $\gamma$ が 5 倍を越えるよう な場合の測位方式として、クロック同期型測位方式 ${ }^{21}$ の有効性を述べ，この方式を可能とするクロック同期 化(クロックオフセット測定)の方法を示す

また，測距衛星の軌道決定精度について検討すると ともに，測距衛星群の検討対象として 24 時間周期の 地球同期衛星及び GPS 衙星に限定し, 離隔率の大き い月周辺での測位精度に関する解析的な関係をシミュ レーションによって確認する．最後に，宇宙航行用の インフラストラクチャとしての有意性を述べる．

\section{2. 衛星測位アルゴリズム}

一般に，レンジ測定に基づく 3 次元測位方式におい ては，位置が既知で，かつ観測点から見て同一線上に

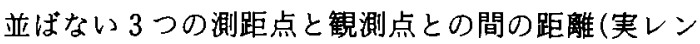
ジ)を測定する必要がある。衛星測位では測距点が衛 
星であり、レンジ測定は衛星から送信される，或いは 衛星により中継される測距電波の伝搬時間を測定する ことにより行われる。

しかし、測距電波の伝般時間が測定されるには、観 測点 (宇宙機) 側では各衛星の測距電波送信のタイミン グが既知でなければならないが，通常，このような条 件を満たすことはなく，宇宙機と各衛星との間の時刻 基準にはズレ，即ちクロックオフセットがある。この クロックオフセットを含んだ伝搬時間より求められた レンジを擬似レンジ, クロックオフセットによって生 じたレンジ誤差をレンジ偏位と呼べば, 通常, 各衛星 のクロックを時刻基準として送信された測距電波の伝 搬時間によって測定されるレンジは擬似レンジであ り，このような擬似レンジを用いた衛星測位では，宇 宙機の 3 次元位置の他に，各衛星とのレンジ偏位を同 時に決定する必要が生じる．そこでGPSでは，ある 衛星の測距電波を基準として他のすへで測距電波の 送信タイミングが既知であるか，この測距電波の時刻 基準に対してすべての測距電波の送信時刻が同期して いるとして，推定すべき変数を 3 次元位置べクトルと 1 つのレンジ偏位(クロックオフセット $\times$ 光速)に減 らすようにする．このように単一のレンジ偏位が含ま れる擬似レンジを使用する擬似レンジ型測位 ${ }^{3)}$ の場合 は， 3 次元測位を行うには 4 基以上の衛星からの測距 電波を受信する必要があり。レンジ偏位を含まない実 レンジを用いる実レンジ型測位 ${ }^{3)}$ の場合よりも必要な 測距電波数は 1 つ増加する。

以上のことを前提として，複数の衛星から同期して 送信された測距電波の伝搬時間より宇宙機の 3 次元位 置べクトル $\boldsymbol{r}$ とレンジ偏位 $q$ を推定する最小自乗法 を適用した衛星測位アルゴリズム4)を記述すると以下 の如くになる. 即ち， $N$ 基の衛星からの測距電波が 受信できるものとして，第 $i$ 番衛星の伝搬時間より求 められる擬似レンジ $S_{i}$ と上記クロックオフセットに 起因するレンジ偏位 $Q_{m}$ が測定值として利用できる場 合，宇宙機の 3 次元位置ベクトル $\boldsymbol{r}$ とレンジ偏位 $q$ を合成した 4 次元測位べクトル $x$ の偏差べクトル

$$
\boldsymbol{\delta} \boldsymbol{x}=\left(\boldsymbol{\delta} \boldsymbol{r}^{\mathrm{T}} \delta q\right)^{\mathrm{T}}
$$

は，測定された擬似レンジ $S_{i}(i=1,2, \cdots, N)$ 及び測 定されたレンジ偏位 $Q_{m}$ と最新の $\boldsymbol{x}$ より算出できる擬 似レンジ及びレンジ偏位との偏差 $\delta S_{i}$ 及び $\delta Q_{m}$ を用 いて.

$$
\begin{aligned}
\boldsymbol{\delta} \boldsymbol{x} & =\left(\boldsymbol{H}^{\mathrm{T}} \boldsymbol{H}\right)^{-1} \boldsymbol{H}^{\mathrm{T}} \boldsymbol{\delta} \boldsymbol{s} \\
\boldsymbol{H} & =\left[\begin{array}{ccccc}
m_{1 x} & m_{2 x} & \cdots & m_{N x} & 0 \\
m_{1 y} & m_{2 y} & \cdots & m_{N y} & 0 \\
m_{1 z} & m_{2 z} & \cdots & m_{N z} & 0 \\
1 & 1 & \cdots & 1 & 1 / \boldsymbol{x}_{\mathrm{c}}
\end{array}\right]^{\mathrm{T}}
\end{aligned}
$$

$$
\delta 8=\left(\begin{array}{lllll}
\delta S_{1} & \delta S_{2} & \cdots & \delta S_{N} & \delta Q_{m} / x_{c}
\end{array}\right)^{\mathrm{T}}
$$

より求められる、ただし，ここでは説明を簡単にする ために擬似レンジ測定誤差の標準偏差はすべて等しい としたが。これは概ね現実的な仮定である， 定レンジ偏位 $Q_{m}$ の測定誤差の標準偏差と測定擬似レ ンジ $S_{i}$ の測定誤差の標準偏差との比の值である. 行 列 $\boldsymbol{H}$ に含まれるべクトル $\boldsymbol{m}_{i}$ は，宇宙機の位置べク トル $\boldsymbol{r}$, 第 $i$ 番衛星の位置ベクトル $L_{i}$ を用いて，以 下の関係式より求められる単位ベクトルである.

$$
\begin{aligned}
& \boldsymbol{m}_{i}=\left(\begin{array}{lll}
m_{i x} & m_{i y} & m_{i z}
\end{array}\right)^{\mathrm{T}} \\
& =\left(\boldsymbol{L}_{i}-\boldsymbol{r}\right) /\left|\boldsymbol{L}_{i}-\boldsymbol{r}\right| \quad(i=1,2, \cdots, N)
\end{aligned}
$$

また，レンジ偏位誤差の大きさを示す比例係数 $x_{\mathrm{c}}$ を大きな值に設定することは，良質なレンジ偏位が測 定值として利用できないことを意味している．そこ で，(3)〜（4)式の $x_{\mathrm{c}}$ を十分に大きな值に設定すれ ば。（2)式の測位アルゴリズムを構成する $\boldsymbol{H}$ 及び $\boldsymbol{\delta} 8$ は,

$$
\begin{aligned}
\boldsymbol{H} & =\left[\begin{array}{cccc}
m_{1 x} & m_{2 x} & \cdots & m_{N x} \\
m_{1 y} & m_{2 y} & \cdots & m_{N y} \\
m_{1 z} & m_{2 z} & \cdots & m_{N z} \\
1 & 1 & \cdots & 1
\end{array}\right]^{\mathrm{T}} \\
\boldsymbol{\delta} \boldsymbol{s} & =\left(\begin{array}{llll}
\delta S_{1} & \delta S_{2} & \cdots & \delta S_{N}
\end{array}\right)^{\mathrm{T}}
\end{aligned}
$$

で置き換えられ，3 次元擬似レンジ型測位アルゴリズ 么と同一の形式が得られる。

衛星搭載のクロックと同様に，宇宙機側にも高安定 なクロックが使用される場合，いったん同期化された 宇宙機の時刻基準は衛星の時刻基準から急速にシフト することはない．従って，レンジ偏位が測定されない 場合でも，宇宙機側クロックのドリフト特性に応じた 補正を加えることにより，時々刻々のレンジ偏位の偏 差 $\delta Q_{m}(t)$ を擬似的に生成することができる. 即ち。 最新の測定レンジ偏位を $Q_{m}(0)$ とすれば、クロック のドリフト特性より推定される経過時間 $t$ における補 正值 $Q_{\mathrm{d}}(t)$ と最新の計算レンジ偏位 $q$ より，レンジ 偏位偏差 $\delta Q_{m}(t)$ は以下の式より求められる.

$$
\delta Q_{m}(t)=Q_{m}(0)+Q_{\mathrm{d}}(t)-q
$$

これは (4)式の $\delta Q_{m}$ として代用できる.

また、クロック補正值には誤差が含まれているた め, レンジ偏位偏差 $\delta Q_{m}(t)$ の標準偏差も経過時間 $t$ と共に增大寸る. 従って，比例係数 $x_{\mathrm{c}}$ を時間関数と みなして，以下の数学的モデルを適用するものとす る.

$$
x_{\mathrm{c}}(t)=\left(x_{\mathrm{co}}^{2}+x_{\mathrm{cr}}^{2} t+\chi_{\mathrm{cp}}^{2} t^{2}\right)^{1 / 2}
$$

ただし， $x_{\mathrm{c} 0}$ はレンジ偏位測定誤差の標準偏差， $x_{\mathrm{cr}}$ は 経過時間の平方根に比例して増大する愦差(ランダム ウォーク)， $x_{\mathrm{cp}}$ は経過時間に比例して增大する誤差 （一定ドリフト）に対応する比例係数てある. 


\section{3. 楖位劣化指数 (DOP)}

通常，衛星の湘位精度は衛星の幾何学的眍置関係よ り求められる測位劣化指数(Dilution of Precision) $に$ よって表され，4 次元测位べクトル $\boldsymbol{x}$ の各成分の誤 差の標準偏差はそれそれの測位劣化指数にレンジ測定 誤差の標準偏差を掛けることによって求められる．宇 宙機が地球表面近傍にあって, 衛星が全天空に概ね均 等に配置されている場合、各種測位方式の湘位劣化指 数は包括的で見通しの良い近似的な関係式, 求められるが, 宇宙機が測距衛星から大きく離れる場 合も同様の関係式を利用することができる.

いま，测位計算の座標系として，第 1 図のように $x$ 軸を宇宙機から地球中心の方向に, $y$ 軸及び $z$ 軸を $x$ 軸に直角でかつ各々に直角な方向に定義し，（5)式の $\boldsymbol{m}_{i}$ を上記座標系て表せば，（2)式より求められる 4 次元測位ベクトルの偏差ベクトル $\delta x$ は上記座標軸に 関して与えられる. 従って，测定レンジの偏差へクト ル $8 \mathbf{8}$ の各成分の誤差は統計的に独立であり，これら の平均值は零，標準偏差は同一で $\sigma_{z}$ とすれば， $\delta x$ の 共分散行列 $\boldsymbol{E}\left(\boldsymbol{\delta} x \boldsymbol{\delta} \boldsymbol{x}^{\mathrm{T}}\right)$ は以下の式で与えられる。

$$
\boldsymbol{E}\left(\boldsymbol{\delta} \boldsymbol{x} \boldsymbol{\delta} \boldsymbol{x}^{\mathrm{T}}\right)=\sigma_{z}^{2}\left(\boldsymbol{H}^{\mathrm{T}} \boldsymbol{H}\right)^{-1}
$$

従って, 行列 $\left(\boldsymbol{H}^{\mathrm{T}} \boldsymbol{H}\right)^{-1}$ の $i$ 行 $j$ 列の成分を $P_{i}$ と置 き， $x$ 軸の位置誤差及び $y$ 軸と $z$ 軸の成分を合成し た位置誤差に対する測位劣化指数をそれそれ RDOP 及びNDOP、レンジ偏位誤差の測位劣化指数を TDOP と定義すれば。

$$
\begin{aligned}
& \mathrm{RDOP}=\left(P_{11}\right)^{1 / 2} \\
& \mathrm{NDOP}=\left(P_{22}+P_{33}\right)^{1 / 2} \\
& \mathrm{TDOP}=\left(P_{44}\right)^{1 / 2}
\end{aligned}
$$

が求められる。このように，ある座標軸に対する各軸 の測位劣化指数は，その座標軸で表された単位べクト $\boldsymbol{m} \boldsymbol{m}_{i}$ を行列 $\boldsymbol{H}$ に代入して，(10)〜(13) 式より算出 される。また、これらの測位劣化指数は一般に GPS

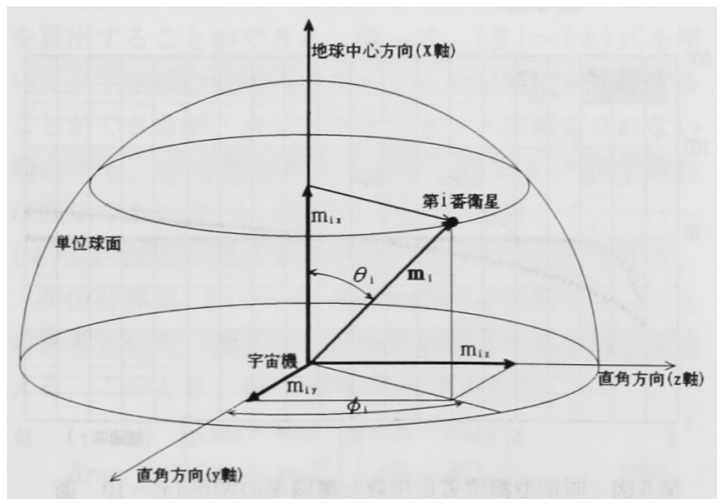

第 1 図 测位計算座標系の定接
の測位精度を表現する DOP に同等なものであり，例 えば $x$ 軸を鉛直方向とみなせば，RDOPはVDOP (Vertical Dilution of Precision), NDOP は HDOP (Horizontal Dilution of Precision)となる。

つぎに，衛星配置条件と衛星測位精度との見通しの 良い解析的な関係を得るために，測距電波源となる衛 星がある視野内で均一に配直されているという前提を 課し，平均的な測位劣化指数を導出する。

いま，第 1 図に示すように，第 $i$ 番衛星の方向を示 す単位べクトル $\boldsymbol{m}_{i}$ と $x$ 軸との成す角度を $\theta_{i}, \boldsymbol{m}_{i}$ の $x$ 軸まわりの回転角を $\phi_{i}$ とすれば，

$$
\begin{aligned}
\boldsymbol{m}_{i} & =\left(m_{i x} m_{i y} m_{i z}\right)^{\mathrm{T}} \\
& =\left(\cos \theta_{i} \sin \theta_{i} \cos \phi_{i} \sin \theta_{i} \sin \phi_{i}\right)^{\mathrm{T}}
\end{aligned}
$$

である。そして， $N$ 基の衛星は $0 \leqq \theta_{i}<\pi / 2$ ，かつ 0 $\leqq \phi_{i}<2 \pi$ の視野内に均一に配置されているものとす れば, $\sin \phi_{i}$ 及び $\cos \phi_{i}$ は $[-1,1]$ の範囲で変動する が, $\sin \theta_{i}$ 及び $\cos \theta_{i}$ は常に正值である. 従って，行 列 $\boldsymbol{H}^{\mathrm{T}} \boldsymbol{H}$ の $i$ 行 $j$ 列の成分を $h_{i j}$ とすれば， $N$ が増加 するとともに，これらの対角成分と $h_{14}$ 及び $h_{41}$ を除 く成分は近似的には無視できる值となる，例えば，

$$
\begin{aligned}
& h_{42}=\sum_{i=1}^{N} \sin \theta_{i} \cos \phi_{i} \\
& h_{43}=\sum_{i=1}^{N} \sin \theta_{i} \sin \phi_{i}
\end{aligned}
$$

は他の成分に比較して十分に小さい。従って， $\boldsymbol{H}^{\mathrm{T}} \boldsymbol{H}$ は近似的に，

$$
\boldsymbol{H}^{\mathrm{T}} \boldsymbol{H}=\left[\begin{array}{cccc}
h_{11} & 0 & 0 & h_{14} \\
0 & h_{22} & 0 & 0 \\
0 & 0 & h_{33} & 0 \\
h_{14} & 0 & 0 & h_{44}
\end{array}\right]
$$

となるため, $\boldsymbol{H}^{\mathrm{T}} \boldsymbol{H}$ の逆行列は容易に計算され，

$$
\begin{aligned}
& \mathrm{RDOP}=\frac{1}{\left(h_{11}-h_{14}^{2} / h_{44}\right\}^{1 / 2}} \\
& \mathrm{NDOP}=\left(1 / h_{22}+1 / h_{33}\right)^{1 / 2} \\
& \mathrm{TDOP}=\frac{1}{\left(h_{44}-h_{14}^{2} / h_{11}\right\}^{1 / 2}}
\end{aligned}
$$

が求められる．ただし，(14)式より，

$$
\begin{aligned}
& h_{11}=\sum_{i=1}^{N} m_{i x}^{2}=\sum_{i=1}^{N} \cos ^{2} \theta_{i} \\
& h_{22}=\sum_{i=1}^{N} m_{i y}^{2}=\sum_{i=1}^{N} \sin ^{2} \theta_{i}\left(1+\cos 2 \phi_{i}\right) / 2 \\
& h_{33}=\sum_{i=1}^{N} m_{i z}^{2}=\sum_{i=1}^{N} \sin ^{2} \theta_{i}\left(1-\cos 2 \phi_{i}\right) / 2 \\
& h_{44}=N+1 / x_{\mathrm{c}}^{2} \\
& h_{14}=\sum_{i=1}^{N} m_{i x}=\sum_{i=1}^{N} \cos \theta_{i}
\end{aligned}
$$

である．さらに，(22)式及び(23)式の $\cos 2 \phi_{i}$ に関す る平均值も無視できるものとすれば，(18)〜 (20)式 は。 


$$
\begin{aligned}
& \mathrm{RDOP}=\frac{\left(1+1 / N x_{\mathrm{c}}^{2}\right)^{1 / 2}}{\left\{N \beta^{2}+\left(\alpha^{2}+\beta^{2}\right) / x_{\mathrm{c}}^{2}\right\}^{1 / 2}} \\
& \mathrm{NDOP}=\frac{2}{\left\{N\left(1-\alpha^{2}-\beta^{2}\right)\right\}^{1 / 2}} \\
& \mathrm{TDOP}=\frac{\left(\alpha^{2}+\beta^{2}\right)^{1 / 2}}{\left\{N \beta^{2}+\left(\alpha^{2}+\beta^{2}\right) / x_{\mathrm{c}}^{2}\right\}^{1 / 2}} \\
& \alpha=(1 / N) \sum_{i=1}^{N} \cos \theta_{i} \\
& \beta^{2}=(1 / N) \sum_{i=1}^{N} \cos ^{2} \theta_{i}-\alpha^{2}
\end{aligned}
$$

となり，測位劣化指数は $\cos \theta_{i}$ の平均值と標準偏差、 衛星可視基数 $N$, 及び比例係数 $\boldsymbol{x}_{\mathrm{c}}$ の関数として示さ れることになる。

ここで，第 2 図を参考にして，测距衛星が衛星軌道 半径を半径とする球面上に一様に分布するものとし， 地球・宇宙機間レンジ $r$ の衛星軌道半径 $L$ に対する比 率を離隔率 $\gamma(=r / L \gg 1)$ とみなせば， $\alpha$ 及び $\beta^{2}$ の平 均値 $\bar{\alpha}$ 及び $\bar{\beta}^{2}$ は，

$$
\begin{aligned}
\bar{\alpha}= & \int_{0}^{\pi}(1 / 2) \sin \theta \cos \left\{\sin ^{-1}(\sin \theta / \gamma)\right\} d \theta \\
\fallingdotseq & 1-\left\{1 /\left(4 \gamma^{2}\right)\right\} \int_{0}^{\pi} \sin ^{3} \theta d \theta \\
& -\left\{1 /\left(16 \gamma^{4}\right)\right\} \int_{0}^{\pi} \sin ^{5} \theta d \theta \\
= & 1-1 /\left(3 \gamma^{2}\right)-1 /\left(15 \gamma^{4}\right) \\
\bar{\beta}^{2}= & \int_{0}^{\pi}(1 / 2) \sin \theta \cos ^{2}\left\{\sin ^{-1}(\sin \theta / \gamma)\right\} d \theta-\bar{\alpha}^{2} \\
\doteqdot & 1-\left\{1 /\left(2 \gamma^{2}\right)\right\} \int_{0}^{\pi} \sin ^{3} \theta d \theta-\bar{\alpha}^{2} \\
= & \left\{1-2 /\left(3 \gamma^{2}\right)\right\}-\left\{1-1 /\left(3 \gamma^{2}\right)-1 /\left(15 \gamma^{4}\right)\right\}^{2} \\
\fallingdotseq & 1 /\left(45 \gamma^{4}\right)
\end{aligned}
$$

となる．従って，測定レンジ偏位が利用できない場 合, 即ち $x_{\mathrm{c}} \gg 1$ のとき，RDOP 及び TDOP の平均值 は(26)式及び(28)式より近似的に

$$
\begin{aligned}
& \mathrm{RDOP}=1 /\left(N \beta^{2}\right)^{1 / 2}=\gamma^{2} /(N / 45)^{1 / 2} \\
& \mathrm{TDOP}=\gamma^{2}\left(1-2 /\left(3 \gamma^{2}\right)\right\}^{1 / 2} /(N / 45)^{1 / 2}
\end{aligned}
$$

であり，測定レンジ偏位が利用できる場合は

$$
\begin{aligned}
& \mathrm{RDOP}=\frac{\left(x_{\mathrm{c}}^{2}+1 / N\right)^{1 / 2}}{\left\{1-2 /\left(3 \gamma^{2}\right)\right\}^{1 / 2}} \fallingdotseq\left(x_{c}^{2}+1 / N\right)^{1 / 2} \\
& \mathrm{TDOP}=\frac{\chi_{\mathrm{c}}}{\left\{1+N x_{\mathrm{c}}^{2} /\left(45 \gamma^{4}\right)\right\}^{1 / 2}} x_{\mathrm{c}}
\end{aligned}
$$

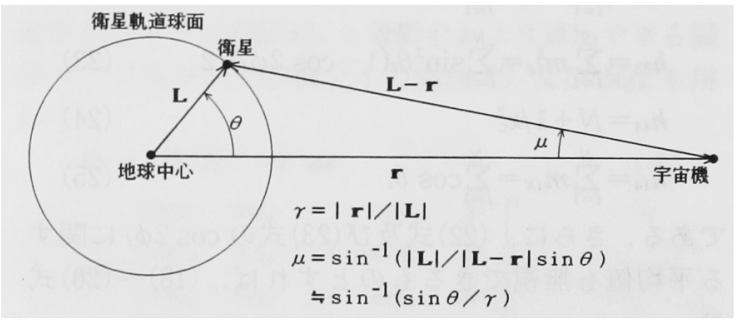

第 2 図 宇宙機・衛星・地球中心の幾何学的関俰
となる，また，NDOPについては，測定レンジ偏位 の有無にかかわらず,

$$
\mathrm{NDOP}=\frac{\gamma}{(N / 6)^{1 / 2}}
$$

となる。

第 3 図〜第 5 図は衛星数を 6 基として，(26)〜（32） 式より算出した測位劣化指数のグラフであるが, 離隔 率 $\gamma$ や測位方式との関係が明らかになっている.

まず，第 3 図は $x_{\mathrm{c}}$ を無限大，即ち測定レンジ偏位 が使用できない場合の湘位劣化指数であるが，(33)式 及び(34)式より明らかなように，擬似レンジ型の測位

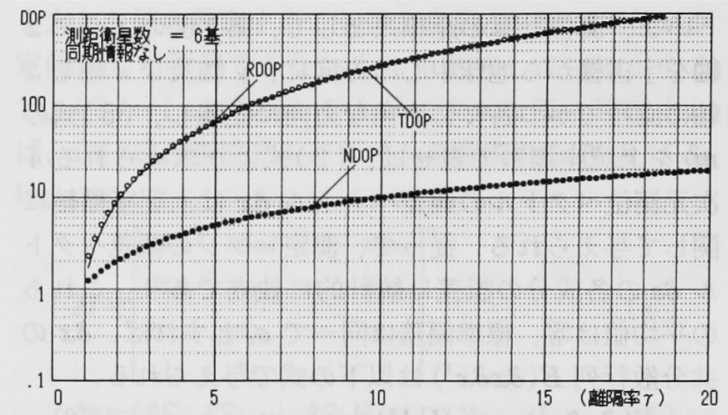

第 3 図擬似レンジ型湘位劣化指数と離隔率の関係(衛星 6 基)

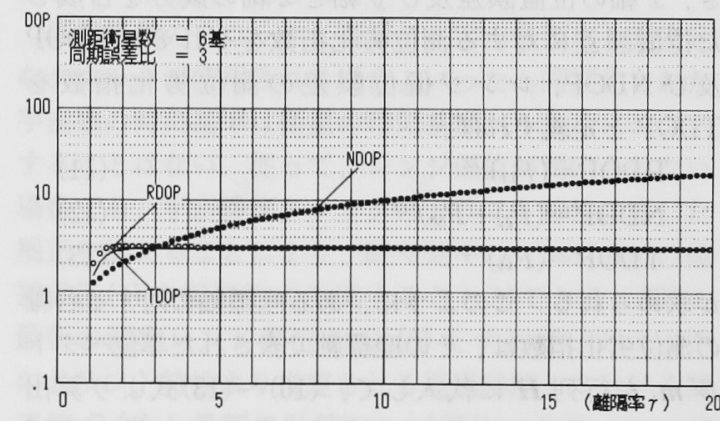

第 4 図 同期型測位劣化指数と離隔率の関係 $\left(x_{\mathrm{c}}=3\right.$ ，得 星 6 基)

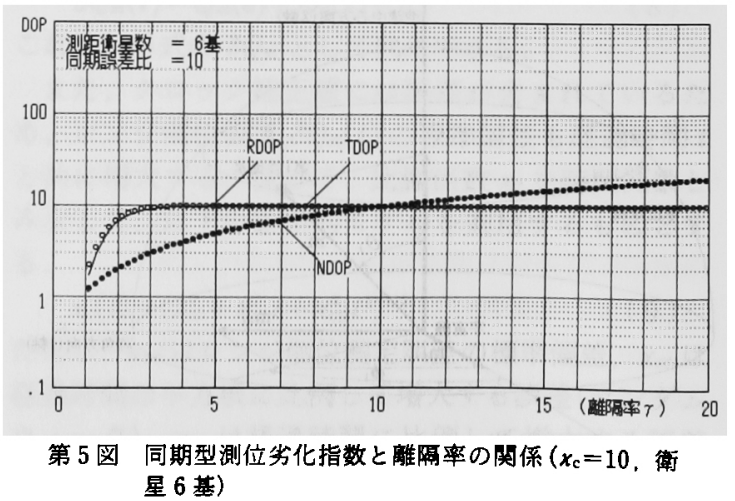




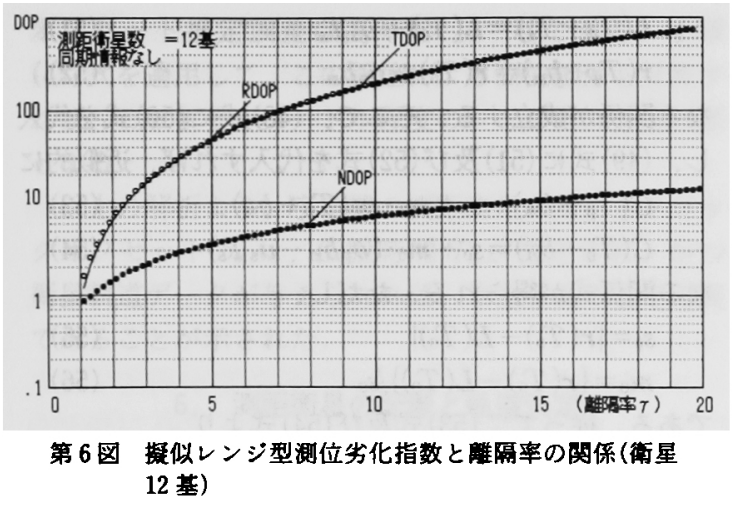

方式では $x$ 軸方向の測位精度は $\gamma$ の増大とともに急 激に劣化する。つぎ，第 4 図及び第 5 図では， $x_{c}$ をそれぞれ 3 及び 10 とした場合であり， $x$ 軸に直角 方向の測位精度は擬似レンジ型測位方式の場合と変わ らないが， $x$ 軸方向の測位精度はレンジ偏位の測定精 度と同等の精度にまで改善されている. 参考のため。 第 6 図には可視衛星数が 12 基の場合の測位劣化指数 を示す

このように, 軌道半径 10 万 $\mathrm{km}$ 以上の高高度衛星 を使用しない限り月近傍では離隔率 $\gamma$ が 5 を越える 大きな值となるため，擬似レンジの測定値のみを使用 した測位方式(この擬似レンジ型測位方式を非同期型 測位方式とも呼ぶ)は地球・月間の衛星航法には不向き であり，前章で述へた測定レンジ偏位を併用するクロ ック同期型の測位方式にの方式は実レンジ型湘位方 式と同等である)が精度上有利であることがわかる.

\section{4. クロック同期型測位方式}

測距電波源である衛星と宇宙機との双方向通信を利 用して，擬似レンジ測定の時刻基準と衛星の時刻基準 とのクロックオフセット $b_{m}$ が測定できるならば，こ れに光速 $C$ を乗じて 2 章 $(8)$ 式の測定レンジ偏位

$$
Q_{m}(0)=C b_{m}
$$

を算出することができる，従って，(2)〜（4)式を用 いて，宇宙機の位置ベクトルとレンジ偏位を更新する ことができるが，クロックオフセットが測定されない 場合でも， $x_{\mathrm{c}}$ を無限大とするか、クロック愦差特性 が既知であれば(8)式及び(9)式を適用して，(2)〜 (4) 式の測位計算式を汎用的に用いることができる.

測位計算式 ( 2$) \sim(4)$ 式が一般的な性質を持つこと

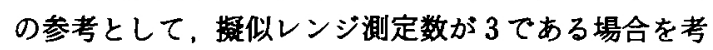
える.このとき， $8 \mathrm{r}$ は解析的に求められ，

$$
\boldsymbol{\delta} \boldsymbol{r}=V_{\mathbf{R}}^{-1}\left[\begin{array}{l}
\left(\boldsymbol{m}_{2} \times \boldsymbol{m}_{3}\right)^{\mathrm{T}} \\
\left(\boldsymbol{m}_{3} \times \boldsymbol{m}_{1}\right)^{\mathrm{T}} \\
\left(\boldsymbol{m}_{1} \times \boldsymbol{m}_{2}\right)^{\mathrm{T}}
\end{array}\right]^{\mathrm{T}}\left[\begin{array}{l}
\delta S_{1}-\delta Q_{m} \\
\delta S_{2}-\delta Q_{m} \\
\delta S_{3}-\delta Q_{m}
\end{array}\right]
$$

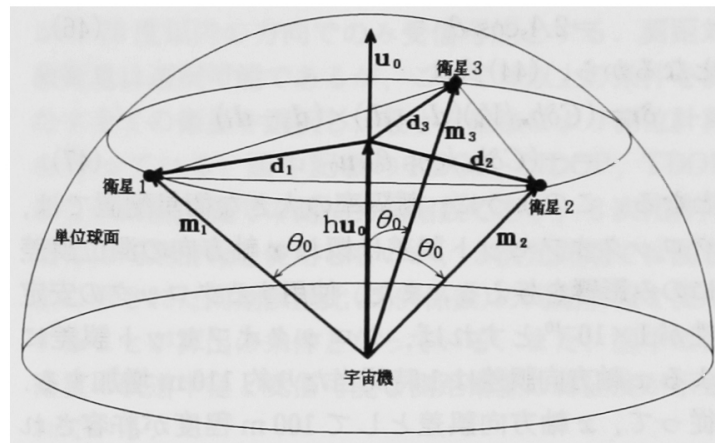

第 7 図 3 衛星単位べクトルの幾何学的関係

$$
V_{\mathrm{R}}=\boldsymbol{m}_{1} \cdot\left(\boldsymbol{m}_{2} \times \boldsymbol{m}_{3}\right)
$$

となり， $\delta q=\delta Q_{m}$ となる。これは擬似レンジ測定值 よりレンジ偏位の成分を取り除いた場合の 3 次元実レ ンジ型測位の解 ${ }^{3}$ となっている。また，擬似レンジ測 定数が 4 以上であっても離隔率の大きな場合は，擬似 レンジの測定值がレンジ偏位の推定精度の向上に大き く寄与しないため, (3)式のような 4 次元べクトル $\boldsymbol{\delta} \boldsymbol{x}$ に関する擬似レンジ型回㷌モデルは不要である。 即ち, $8 x$ よりレンジ偏位 $\delta q$ を削除した 3 次元位置 ベクトル偏差 $\delta r$ に関する回帰モデル゙) として。

$$
\begin{aligned}
& \boldsymbol{\delta} \boldsymbol{r}=\boldsymbol{H} \boldsymbol{\delta} \boldsymbol{s}+\boldsymbol{\varepsilon} \\
& \boldsymbol{H}=\left[\begin{array}{llll}
m_{1 x} & m_{2 x} & \cdots & m_{N x} \\
m_{1 y} & m_{2 y} & \cdots & m_{N y} \\
m_{1 z} & m_{2 z} & \cdots & m_{N z}
\end{array}\right]^{\mathrm{T}} \\
& \boldsymbol{\delta s}=\left(\begin{array}{lll}
\delta S_{1}-\delta Q_{m} & \cdots & \left.\delta_{N}-\delta Q_{m}\right)^{\mathrm{T}}
\end{array}\right.
\end{aligned}
$$

を適用し、（2）式を用いて測位計算を行っても測位精 度に大差はない，この性質は，第 4 図，第 5 図の $\gamma \geqq$ 5 での TDOPの值が $x_{c} に$ 等しいことからも判断され る，従って，測定值 $\delta Q_{m}$ を回㷌モテルに組み入れず, (43)式の如く擬似レンジの補正值として使用しても精 度上変わらない

つぎに、クロックオフセットが間久的に測定される 場合を想定して，クロックオフセットの䛠差 $\delta b_{m}$ の 測位誤差に対する影響を解析的に検討する。

いま，(39)式を参考にして，クロックオフセット測 定誤差 $\delta b_{m}$ による位置誤差べクトル $\delta r$ を求めると，

$$
\delta r=\left(C \delta b_{m} / V_{R}\right)\left(m_{1}-m_{2}\right) \times\left(m_{3}-m_{1}\right)
$$

となる，そこで，第 7 図を参考にして，単位べクトル $\boldsymbol{m}_{i}$ を外接円の中心を通る方向と，これに直角な方向 の成分に分解すれば。

$$
\boldsymbol{m}_{i}=h u_{0}+d_{i}
$$

となる. 従って，3つの単位べクトル $\boldsymbol{m}_{i}$ の頂点から 成る 3 角形の面積を $A_{\mathrm{s}}$, 単位へクトル $\boldsymbol{m}_{2}$ と単位べ クトル $\boldsymbol{u}_{0}$ のなす角を $\theta_{0}$ とすれば，

$$
V_{R}=h u_{0} \cdot\left(d_{1} \times d_{2}+d_{2} \times d_{3}+d_{3} \times d_{1}\right)
$$


$=2 A_{\mathrm{s}} \cos \theta_{0}$

となるから，(44)式は

$$
\begin{aligned}
\delta \boldsymbol{r}= & \left(C \delta b_{m} / V_{\mathrm{R}}\right)\left(\boldsymbol{d}_{1}-\boldsymbol{d}_{2}\right) \times\left(\boldsymbol{d}_{3}-\boldsymbol{d}_{1}\right) \\
& =-\left(C \delta b_{m} / \cos \theta_{0}\right) \boldsymbol{u}_{0}
\end{aligned}
$$

となる，このように，雕隔率の大きな衛星配置では， クロックオフセット誤差は概ね $x$ 軸方向の測位誤差 にのみ影響を与える．また，使用するクロックの安定 性が $1 \times 10^{-10}$ とすれば，クロックオフセット誤差に よる $x$ 軸方向誤差は 1 時間当たり約 $110 \mathrm{~m}$ 増加する. 従って， $x$ 軸方向誤差として $100 \mathrm{~m}$ 程度が許容され るならば, クロックオフセットの測定は 1 時間に概ね 1 回でよいことになる。

\section{5. クロックオフセットの推定方法}

3 章の解析より, 離隔率の大きい衛星配置において も，同期型測位方式を適用することにより高精度な測 位を達成できることが明らかになったが，宇宙機側の 衛星側に対するクロックオフセット $b_{m}$ は，宇宙機側 の時刻基準に同期して送信した測距電波を特定の測距 衛星(あるいは地上局)が受信し，その伝搬時間を測定 することにより推定可能である2)，以下，第 8 図を参 考にして，その一例を説明する。

いま，宇宙機及び当該衛星の地球を原点とする位置 ベクトルをそれぞれ $\boldsymbol{r}$ 及び $\boldsymbol{L}$ ，速度を $\boldsymbol{u}_{\mathrm{p}}$ 及び $\boldsymbol{u}_{\mathrm{s}}$ と し，宇宙機が自己の時刻を基準として測定した衛星か らの測距電波(時刻 $T_{0}$ に送信)の伝搬時間を $T_{\mathrm{p}}$, 衛 星が自己の時刻を基準として測定した宇宙機からの測 距電波(時刻 $T_{0}+b_{m}$ に送信)の伝搬時間を $T_{\mathrm{s}}$ とすれ ば,

$$
\begin{aligned}
& C\left(T_{\mathrm{p}}+b_{m}\right)=\left|\boldsymbol{r}\left(T_{0}+T_{\mathrm{p}}+b_{m}\right)-\boldsymbol{L}\left(T_{0}\right)\right| \\
& C\left(T_{\mathrm{s}}-b_{m}\right)=\left|\boldsymbol{L}\left(T_{0}+T_{\mathrm{s}}\right)-\boldsymbol{r}\left(T_{0}+b_{m}\right)\right| \\
& \boldsymbol{r}\left(T_{0}+T_{\mathrm{p}}+b_{m}\right)=\boldsymbol{r}\left(T_{0}\right)+\boldsymbol{u}_{\mathrm{p}} \cdot\left(T_{\mathrm{p}}+b_{m}\right)
\end{aligned}
$$

$$
\begin{aligned}
& \boldsymbol{L}\left(T_{0}+T_{\mathrm{s}}\right)=\boldsymbol{L}\left(T_{0}\right)+\boldsymbol{v}_{\mathrm{s}} T_{\mathrm{s}} \\
& \boldsymbol{r}\left(T_{0}+b_{m}\right)=\boldsymbol{r}\left(T_{0}\right)+\boldsymbol{v}_{\mathrm{p}} b_{m}
\end{aligned}
$$

なる関係が成立する，そこて，(48)式に(50)式を代入

し，(49)式に(51)及び(52)式を代入すれば，近似的に

$$
\begin{aligned}
& C\left(T_{\mathrm{p}}+b_{m}\right)=s_{0}+m_{0} \cdot v_{\mathrm{p}}\left(T_{\mathrm{p}}+b_{m}\right) \\
& C\left(T_{\mathrm{s}}-b_{m}\right)=s_{0}+m_{0} \cdot\left(v_{\mathrm{p}} b_{m}-v_{\mathrm{s}} T_{\mathrm{s}}\right)
\end{aligned}
$$

なる関係式が得られる。ただし，

$$
\begin{aligned}
& s_{0}=\left|r\left(T_{0}\right)-L\left(T_{0}\right)\right| \\
& m_{0}=\left\{r\left(T_{0}\right)-L\left(T_{0}\right)\right\} / s_{0}
\end{aligned}
$$

である．従って，(53)式及び(54)式より .

$$
\begin{aligned}
b_{m}= & \left(T_{\mathrm{s}}-T_{\mathrm{p}}\right) / 2+T_{\mathrm{p}}\left(m_{0} \cdot v_{\mathrm{p}}\right) / 2 C \\
& +T_{\mathrm{s}}\left(m_{0} \cdot v_{\mathrm{s}}\right) / 2 C
\end{aligned}
$$

が求められ， $m_{0} \cdot v_{\mathrm{p}}$ 及び $m_{0} \cdot v_{\mathrm{s}}$ が既知であれば $b_{m}$ が 決定できることになる．

まず，(57)式の $m_{0} \cdot v_{p}$ は宇宙機の速度 $v_{p}$ の $m_{0}$ 方 向成分であり，測距衛星からの測距電波の周波数 $f_{0}$ のドップラー周波数変移量 $\delta f$ よ求められる. 即 ち.

$$
\begin{aligned}
\boldsymbol{m}_{0} \cdot \boldsymbol{v}_{\mathrm{p}}= & -\left(\delta f / f_{0}\right) C \\
& +\left(1+\delta f / f_{0}\right) \boldsymbol{m}_{0} \cdot \boldsymbol{v}_{\mathrm{s}}
\end{aligned}
$$

であるから，(57)式は以下の式に書き換えられる.

$$
\begin{aligned}
b_{m}= & \left(T_{\mathrm{s}}-T_{\mathrm{p}}\right) / 2-T_{\mathrm{p}}\left(\delta f / f_{0}\right) / 2 \\
& +\left\{T_{\mathrm{p}}\left(1+\delta f / f_{0}\right)+T_{\mathrm{s}}\right\}\left(\boldsymbol{m}_{0} \cdot \boldsymbol{v}_{\mathrm{s}}\right) / 2 C
\end{aligned}
$$

また，(59)式の $m_{0} \cdot v_{\mathrm{p}}$ は最新の $\boldsymbol{r}\left(T_{0}\right)$ と衛星軌道 要素より求められる. 即ち， $m_{0}$ は宇宙機で推定され ている最新の $\boldsymbol{r}\left(T_{0}\right)$ と $\boldsymbol{L}\left(T_{0}\right)$ を(55)式及び $(56)$ 式に 代入することにより， $\boldsymbol{v}_{\mathrm{s}}$ は衛星軌道要素より決定て きる．使用する最新の $\boldsymbol{r}\left(T_{0}\right)$ にはクロック同期誤差等 による誤差が含まれているが、この誤差により $b_{m}$ の 推定に大きな誤差が生じることはない，参考に，宇宙 機・衛星間距離 $s_{0}$ を 10 万 $\mathrm{km}$ とし， $r\left(T_{0}\right) に 100 \mathrm{~km}$ の器差が含まれていたとしても，これによるクロック

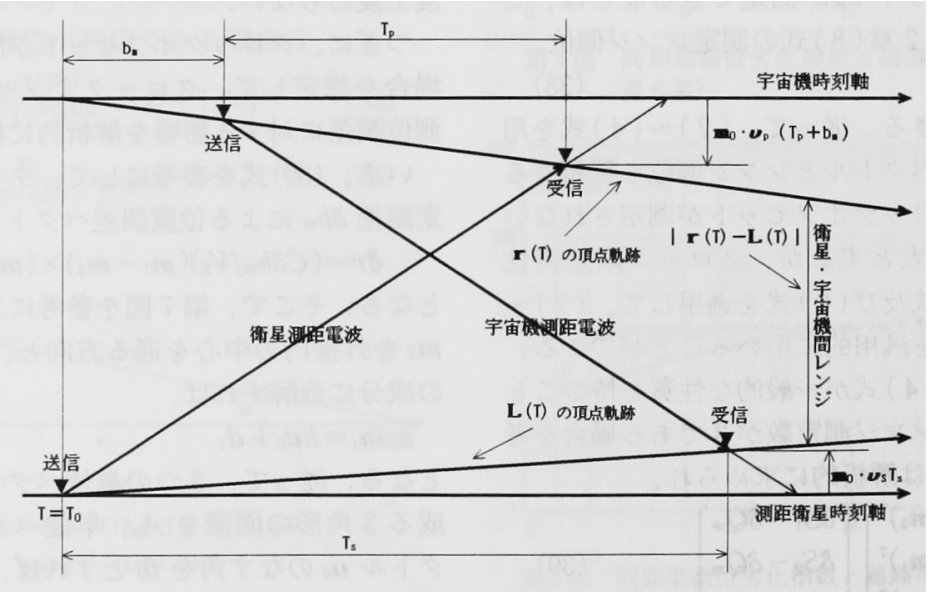

第 8 図 伝搬時間とクロックオフセットの関係 
オフセット推定誤差は高々 $4 \times 10^{-9}$ 秒である．4 章 （47）式を適用して、この誤差による測位誤差を計算す ればおおよそ1メートル程度のレンジ方向位置誤差 となる。

以上の解析より，宇宙機の測距衛星に対するクロッ クオフセット $b_{m}$ は，伝搬時間 $T_{\mathrm{s}}$ が測定され，かつ 衛星軌道データが与えられれば，宇宙機側で推定可能 であることが示された。

\section{6. 測距衛星の眍置と軌道決定}

クロック同期条件を用いる同期型測位方式では，お 互いに重ならないか，直線上に並ばない 3 基の衛星か らの測距電波が受信できればよい，しかし，地球より 遠く離れて衛星を眺める限り，静止衛星もまた周回す る衛星であり，時々刻々に衛星の配置関係は変化す る。もちろん，地球による食や測距衛星がお互いに接 近したり直線的に並ぶことがあるため，3基の衛星で は測位精度が著しく劣化することもある．従って，以 下では地球周辺に 6 基の衛星を配置するものとして， 衛星配置と軌道決定精度の問題について検討する。

第 9 図には静止軌道上に 2 基，60 度傾斜角の地球 同期軌道上に 4 基の衛星を配置した場合の衛星配置状 態と测位劣化指数を示す 図中の衛星時刻は衛星軌道 上の衛星位置を定めるパラメータであり，単に時刻に よって衛星位置を変えるために使用している，衛星位 置・は宇宙機から見た方向であり，同心円の中央にあ る地球の方向との成す角度とその回転角により表され ている．観測位置(宇宙機の位置)は赫緯，赤経及び地 球からのレンジで与えられ，この図では赤緯 25 度， 赤経 150 度で，レンジは 10 万 $\mathrm{km}$ である。このレン ジにより地球の陰影角度や衛星配置笧囲は変化する が、これらの条件は測位誤差のシミュレーションの際 に使用される，衛星が陰影内に位置する場合，測距電 波は受信できないとする．GPS 衛星に対してはさら に送信角度 (受信幅)を設け，測距電波は地球中心方向

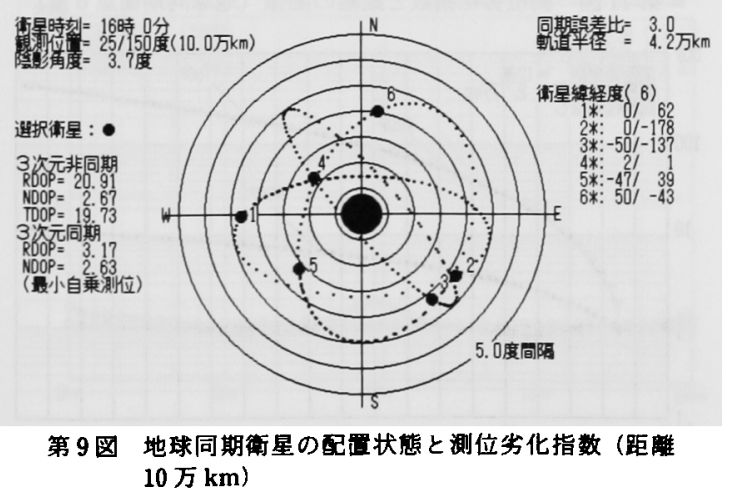

から 70 度以内の方向でみ受信可能とする．測距対 象衛星は選択可能であるが，ここでは以上の条件を满 たす全ての衛星を選択し，最小自乗法により測位計算 を行っている．図中記載の RDOP，NDOP，TDOP はこの衛星配置での測位劣化指数であり，3 次元非同 期では同期情報を使用しないが，3 次元同期では図右 上に示された同期誤差比 (比例係数)の同期情報を使用 することが算出の条件となっている，また，図中には 衛星の軌道半径と受信可能な測距衛星の緯経度が示さ れている。

第 10 図にはレンジ 5 万 $\mathrm{km}$ から見た GPS 衛星(電 波送信幅を片側 70 度とする)の配置状態を示すが，図 中に示す測位劣化指数より， $\gamma<2$ ては湘位精度は良 好であることがわかる．また，第 3 図〜第 6 図と第 9 図及び第 10 図を比較すると，湘位劣化指数の解析と シミュレーションの結果は概ね一致している.

ここで，達成できる測位精度と衛星の軌道半径の関 係について概略検討する．測位精度の観点からは，離 隔率を小さくするために測距衛星はできるだけ高高度 に配置することが望ましい。しかし，高高度になると 地球局による衛星軌道決定精度は少化し、レンジ測定 誤差を増大せしめることとなる。

いま，当該衛星と 3 地上局間の測距電波の往復伝搬 時間より，衛星・地上局間レンジ $Z_{1}, Z_{2}$ 及び $Z_{3}$ が測定 できるものとしよう，そして，衛星位置べクトルを $L ， 3$ つの地球局位置ベクトルを $G_{1}, G_{2}$ 及び $G_{3}$ とす れば、衛星と 3 地上局を結ぶ方向の単位ベクトル $\boldsymbol{n}_{i}$ は、

$$
\boldsymbol{n}_{i}=\left(\boldsymbol{G}_{i}-\boldsymbol{L}\right) /\left|\boldsymbol{G}_{i}-\boldsymbol{L}\right| \quad(i=1,2,3)
$$

である、従って、実レンジ型測位アルゴリスム ${ }^{3)}$ を適 用すれば，衛星レンジの偏差 $\delta Z_{i}$ と衛星位置ベクトル 偏差 $\boldsymbol{\delta} \boldsymbol{L}$ に関する以下の関係式が得られる.

$$
\delta L=V_{N}^{-1}\left[\begin{array}{l}
\left(n_{2} \times n_{3}\right)^{\mathrm{T}} \\
\left(n_{3} \times n_{1}\right)^{\mathrm{T}} \\
\left(n_{1} \times n_{2}\right)^{\mathrm{T}}
\end{array}\right]^{\mathrm{T}}\left[\begin{array}{l}
\delta Z_{1} \\
\delta Z_{2} \\
\delta Z_{3}
\end{array}\right]
$$

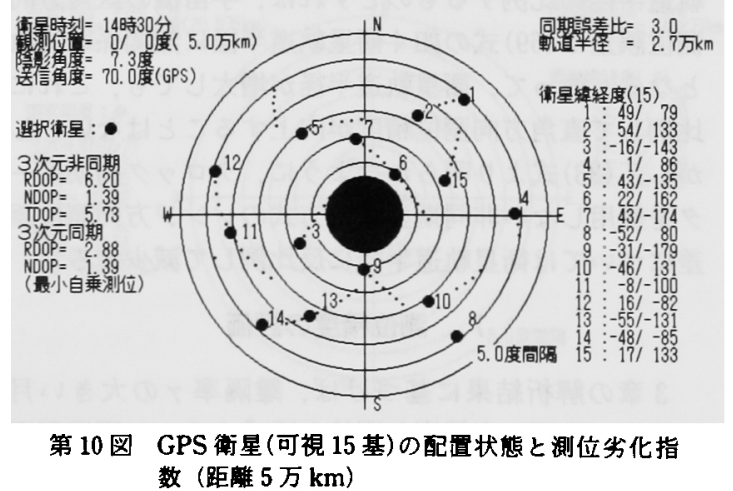




$$
V_{N}=\boldsymbol{n}_{1} \cdot\left(\boldsymbol{n}_{2} \times \boldsymbol{n}_{3}\right)
$$

また，第 1 図のべクトル $\boldsymbol{m}_{\boldsymbol{i}}$ をべクル $\boldsymbol{n}_{\boldsymbol{i}}$ とみな して，それらの頂点を通る外接円を考え，衛星と外接 円の中心を通る方向に $x$ 軸，これに直角な方向に $y$ 軸及び $z$ 軸を定義すれば，衛星位置決定誤差の指標 として測位劣化指数 (26) 式及び(27)式が適用できる. そこで，地上局数として $N=3$ ，測距電波の往復伝搬 時間より実レンジが測定されるものとして $x_{\mathrm{c}} \rightarrow 0$ とす れば。

$$
\begin{aligned}
& \mathrm{RDOP}=1 /\left(3^{1 / 2} \cos \theta_{0}\right) \\
& \mathrm{NDOP}=2 /\left(3^{1 / 2} \sin \theta_{0}\right)
\end{aligned}
$$

となる．従って，衛星位置愦差べクルの絶対值に関 する測位劣化指数を PDOP とすれば，

$$
\begin{aligned}
\mathrm{PDOP} & =\left(\mathrm{RDOP}^{2}+\mathrm{NDOP}^{2}\right)^{1 / 2} \\
& =\left\{(1 / 3) \cos ^{-2} \theta_{0}+(4 / 3) \sin ^{-2} \theta_{0}\right\}^{1 / 2}
\end{aligned}
$$

となり．衛星軌道半径が GPS 衛星軌道以上では

$$
\mathrm{PDOP} \fallingdotseq(4 / 3)^{1 / 2} \theta_{0}^{-1}
$$

なる近似式を用いることができる，ただし， $\theta_{0}$ は $x$ 軸とベクトル $n_{i}$ の成す角度である，従って，地球同 期軌道を適用する場合は，地上局を充分に離して設置 しても PDOPは 10 以上となる。

つきに, $R e=$ 地球半径, $L=$ 衛星軌道半径とし $\tau$

$$
\theta_{0} \fallingdotseq k \operatorname{Re} / L \quad(k=0.5 \sim 0.9)
$$

で近似すれば，衛星位置誤差の標準偏差 $\sigma_{L}$ は衛星レ ンジ測定誤差の標準偏差を $\sigma_{z}$ として，(66)式より，

$$
\sigma_{L} \fallingdotseq(4 / 3)^{1 / 2}(L / k R e) \sigma_{z}
$$

となる，そこで，上記の衛星位置誤差を測距衛星・宇 宙機間レンジ測定誴差の支配的な要素とみなして, 宇 宙機のレンジに直角な方向の測位䛊差の標準偏差 $\sigma_{N}$ を(37)式を用いて算出すると，

$$
\begin{aligned}
\sigma_{N} & =\gamma /(N / 6)^{1 / 2} \times \sigma_{L} \\
& \fallingdotseq(r / L) /(N / 6)^{1 / 2} \times(4 / 3)^{1 / 2}(L / k R e) \sigma_{z} \\
& =(8 / N)^{1 / 2}(r / k R e) \sigma_{z}
\end{aligned}
$$

となる，即ち，衛星位置決定誴差が(68)式の如く衛星 軌道半径に比例するものとすれば，宇宙機の直角方向 測位誤差は (69)式の如く衛星軌道半径に無関係な関数 となる，従って，衛星軌道半径が増大しても，これに 比例して直角方向測位精度が向上することはないし かし，(33)式より明らかなように，クロック同期デー 夕を使用しない非同期型測位方式のレンジ方向測位諡 差については衛星軌道半街に反比例して減少する。

\section{7. 測位精度の評価}

3 章の解析結果に基づけば，離隔率 $\gamma$ の大きい月 近傍及び月面で高精度な測位を達成するには同期型測 位方式の適用が望ましい，第 $11 \sim 12$ 図には，測位
精度と地球中心までの距離の関係を容易に読み取れる ように，测距衛星として 6 章に示した地球同期型衛星 (静止を含めて 6 基)及び GPS 衛星(可視 12 基)の場 合に限定して，擬似レンジ型測位の測位少化指数を示 す．同期型測位の場合，NDOPは擬似レンジ型と同 じグラフであり，RDOP 及びTDOPについては第 4 図の如く $\gamma \geqq 5$ て RDOP $\fallingdotseq x_{\mathrm{c}}, \mathrm{TDOP} \fallingdotseq x_{\mathrm{c}}$ となるから， 省略する。

まず参考に，第 13 図には GPS 衛星が利用できる

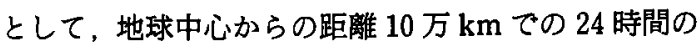
測位精度を示す. 図中右上の括弧内の数値は湘位出化 指数の関係式の性質から，ます測位誤差の逆数の自乗 平均を計算し，つぎにこの逆数の平方根を測距誤差で 割ることにより算出したものであり，例えばRDOP は約 36 である。第 12 図ではRDOPは約 30 である が、レンジ 10 万 $\mathrm{km}$ では可視衛星は 12 基よりも減少 するから，(26)式の可視衛星数との関係を考虑すれ ば、これらは概ね一致していると言える。また， $x$ 軸 (レンジ方向)の測位誤差は直角方向の測位誤差に比較 して 10 倍程度大きいが，この傾向も解析結果とよく 一致している。

第 9 図に示した 6 基の地球同期衛星群を利用する と，第 14 図のように同期型測位でなくても RDOPは 半隇するが，この衛星配置ては一時的に測位精度の劣 化する時間帯が生じる.そこで, $x_{c}=3$ のクロック同

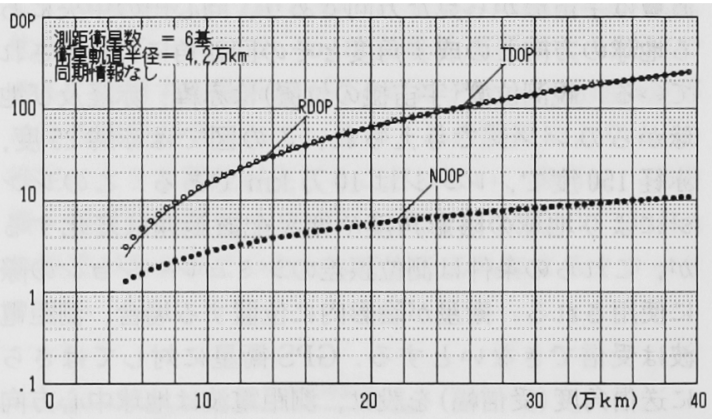

第 11 図 測位分化指数と距離の関倸（地球同期衛星 6 基）

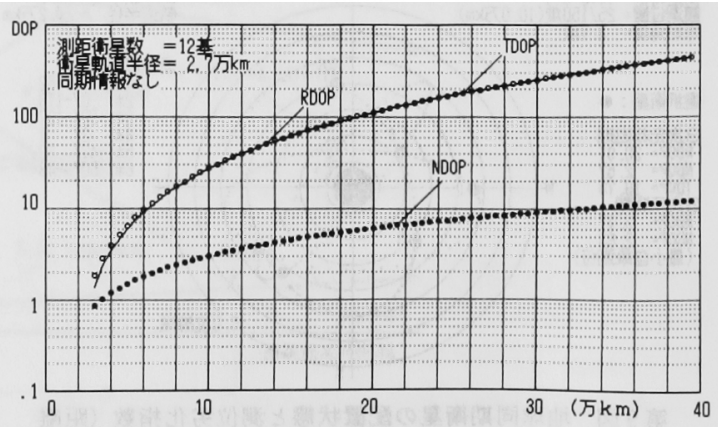

第 12 図 測位劣化指数と距離の関係（GPS 衛星 12 基) 
期情報(レンジ偏位)を併用するものとすれば，第 15 図の如く測位劣化指数はすべて 3 程度となる.第 16 図には第 15 図と同じ条件て, 時刻 $14: 00$ での衛星配 置状態と各測位方式の測位劣化指数を示す．さらに， レンジと渭位精度の関係を如実に示すため, 第 17 図 と第 18 図には 20 万 $\mathrm{km}$ の地点で同期型の測位精度 と時刻 $14: 00$ で衛星配置関係を示す，第 11 図によ れば，10万 $\mathrm{km}$ 地点と 20 万 $\mathrm{km}$ 地点での擬似レンジ 型測位のレンジ方向測位劣化指数 RDOP はそれぞれ 15,60 , 直角方向測位劣化指数 NDOP はそれそれ
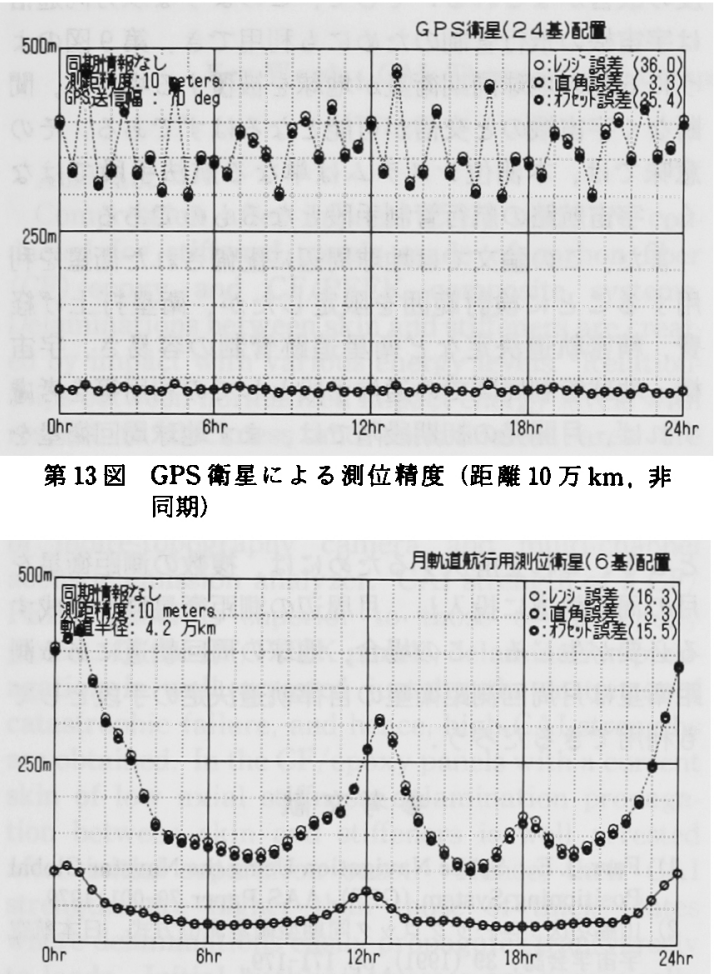

第 14 図地球同期衛星による測位精度（6 基，距離 10 万 km, 非同期)

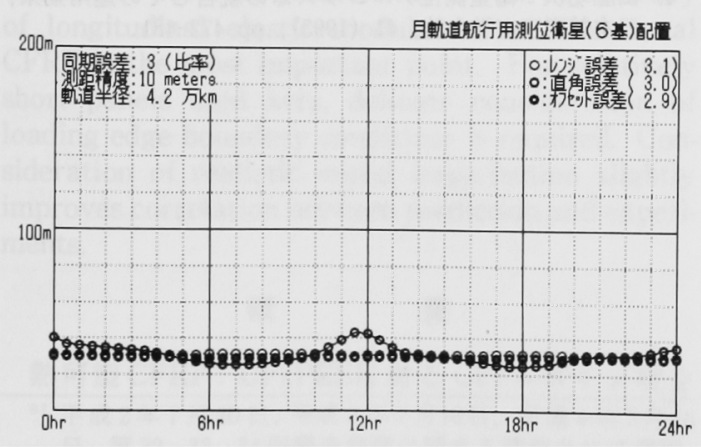

第 15 図地球同街衡星による測位精度（6基，距離 10 万 $\mathrm{km}$, 同期)
3.6，5.5 程度であるから，衛星配置のばらつきを考 慮すれば、これらの解析結果はシミュレーションの結 果と概ね一致していると判断される。

月近傍あるいは月面での測位となると，擬似レンジ 型(非同期型)測位の RDOP は 200 を越えることが第 11 図よりかかる．従って，もはや擬似レンジ型での 高精度な測位は期待できない。第 19 図には $x_{c}=3$ と した場合の 38 万 $\mathrm{km}$ 地点での測位精度の時間的変化 を,第 20 図には時刻 18：00での衛星配置状態と各測 位方式の測位劣化指数を示す これらの結果も第 11

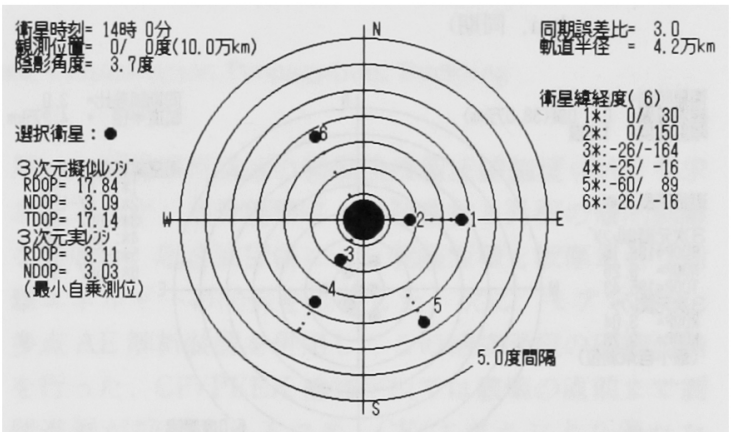

第 16 図地球同期衛星の配置状態と測位少化指数(距離 10 万 $\mathrm{km}$ )

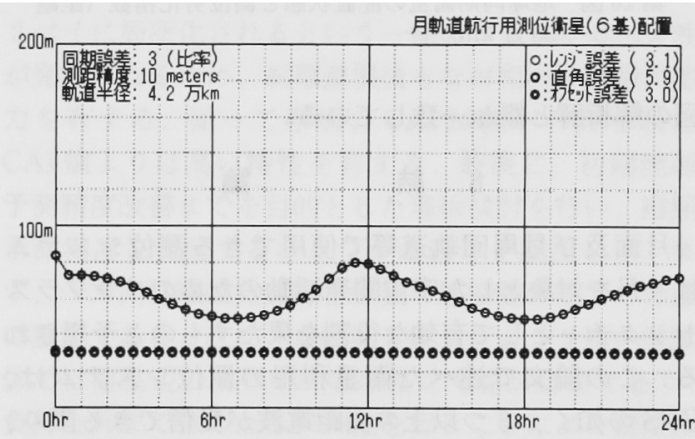

第 17 図 地球同期衛星による測位精度（6 基, 距離 20 万 $\mathrm{km}$ ，同期）

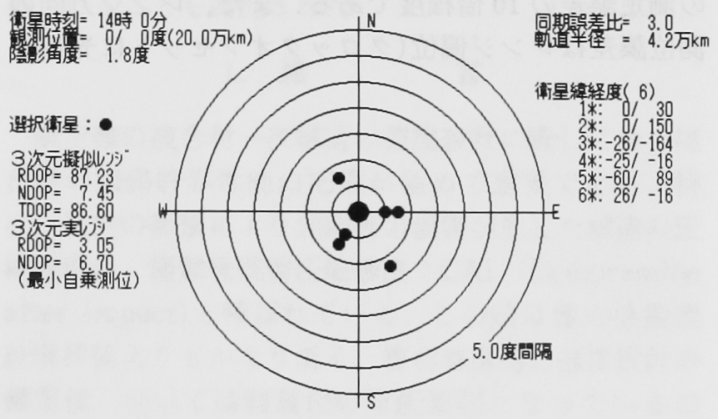

第 18 図地球同期衛星の配置状態と測位少化指数（距離 20 万 $\mathrm{km}$ ) 


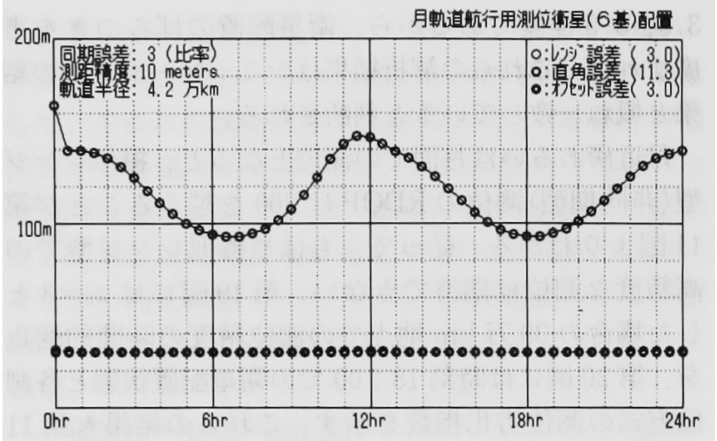

第 19 図 地球同期衛星による測位精度（6 基、距離 38 万 $\mathrm{km}$, 同期)

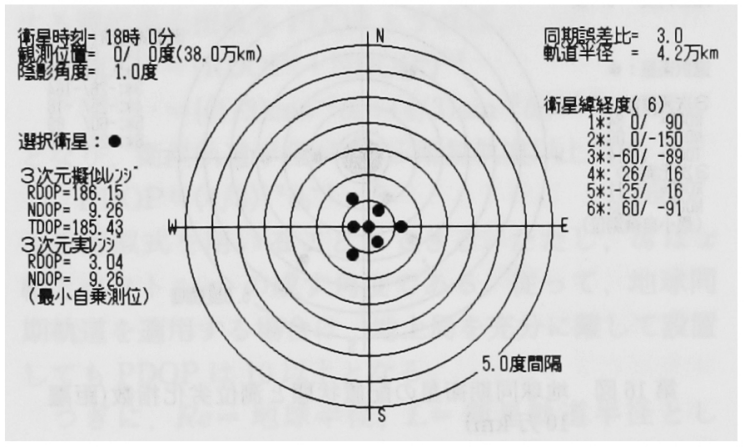

第 20 図地球同期衛星の配置状態と測位劣化指数（距離 38 万 $\mathrm{km}$ )

図の解析解と概ね一致している。
8. 結
論

月面及び月周回軌道等で使用できる測位システム は，月を対象とした宇宙開発活動のためのインフラス トラクチャとして有効な役割を果たすものと予想され る.この論文で述べた衛星利用の測位システムは， GPS の如く，3 つ以上の測距電波が受信できる限り， 連続した位置と速度の情報を提供するものであり，月 周辺でのレンジに直角な方向の測位詥差は擬似レンジ の測定誤差の 10 倍程度である。また、レンジ方向の 測位誤差はレンジ偏位(クロックオフセットに光速を
掛けた距離)の測定誤差のレベルにまで低減すること ができる，従って，同期型測位方式を適用した測位端 末は宇宙機の月軌道への投入と離脱，月面への着陸と 離陸、月面車両の移動等での航法手段あるいは他の航 法システムの補完的手段として利用でき，月ミッショ ンでのより効率的な活動を支援するものとなろう。

月ミッションにおいては，通信手段もまた宇宙活動 のための重要なインフラストラクチャである．同期型 測位方式で通信手段は不可欠のものであり．衛星， 宇宙機双方の測距電波の間久的な送受信により測位精 度の改善がなされる，そして，このような双方向通信 は宇宙機の飛行管制のためにも利用でき，第 9 図のよ うに 6 基の地球同期衛星が地球を被覆する場合は，間 断なく宇宙機のと交信が可能となるはずである．その 意味では，本測位システムは単なる航法手段ではな く，宇宙航路の航行管制手段となるものである.

また，この論文ては地球周辺に配備された衛星を利 用することに検討範囲を限定したが，衛星打上げ経 費，精密軌道決定など衛星追跡管制の容易さ，宇宙 機・地球管制局間ての通信手段としての利用等を考虑 すれば，月開発の初期段階では，まず地球周回衛星を 使用することが妥当であると思われる．しかし，宇宙 機が月面の裏側に位置する場合は当然ながら測位不能 となる．これを解決するためには，複数の測距衛星を 月の周回軌道に投入し, 月周辺の測距衛星群を構成す る必要が生じる．この場合，地球の周回軌道にある測 距衛星は月周回測距衛星の自律軌道決定の手段として も利用できるだろう。

\section{参考文献}

1) Farr, J. E. : Space Navigation Using the Navstar Global Positioning System (GPS), AAS Paper 79-001, 1979.

2）山脇功次：エーザクロック同期型衛星測位方式，日本航空 宇宙学会誌, 39 (1991), pp. 171-179.

3）山脇功次：最小自乗推定に基づく衛星測位の精度解析, 日 本航空宇宙学会誌。 40 (1992)，pp. 543-552.

4) 山䐗功次：衛星測位アルゴリスムの統合とその飓用効果. 日本航空宇宙学会誌, 41 (1993)，pp. 472-481. 